ISSN 0103-5150

Fisioter. Mov., Curitiba, v. 28, n. 1, p. 41-48, Jan./Mar. 2015

Licenciado sob uma Licença Creative Commons

DOI: http://dx.doi.org.10.1590/0103-5150.028.001.A004

(c)

\title{
Acute cardiovascular responses to a session of Manual Lymphatic Drainage
}

\author{
Respostas cardiovasculares agudas a uma \\ sessão de drenagem linfática manual
}

\author{
Plínio dos Santos Ramos ${ }^{[a, c]}$, Isabelle Regina Moreira Marinho Cunha ${ }^{[a]}$, Mariana Cristina Rachel ${ }^{[a]}$, \\ Priscilla Stephan Souza Pacca ${ }^{[a]}$, Ana Paula Ferreira ${ }^{[a, b, c]}$, Djalma Rabelo Ricardo ${ }^{[a, c] *}$ \\ [a] Faculdade de Ciências Médicas e da Saúde de Juiz de Fora (FCMS-JF), Juiz de Fora, MG, Brazil \\ [b] Universidade do Estado do Rio de Janeiro (UERJ), Rio de Janeiro, RJ, Brazil \\ [c] Hospital Maternidade Therezinha de Jesus, Juiz de Fora, MG, Brazil
}

\section{Abstract}

Introduction: Manual Lymphatic Drainage (MLD) creates pressure differentials to promote the movement of lymph and interstitial fluid, for their relocation into the bloodstream and can thus act on the variables responsible for determining blood pressure (BP). Objective: To investigate the behavior of hemodynamic parameters, such as BP and Heart Rate (HR) during and immediately after a session of MLD. Materials and methods: 23 healthy young volunteers with a mean age of $22 \pm 2.97$ years (18-29), underwent a session of

\footnotetext{
* PSR: PhD, e-mail: pliniosramos@gmail.com IRMMC: Grad., e-mail: isabelleicm@hotmail.com MCR: Grad., e-mail: marianacristinarachel@hotmail.com PSSP: Grad., e-mail: pripacca@hotmail.com APF: MSc student, e-mail: paulaffisio@gmail.com DRR: PhD, e-mail: djalmaricardo@suprema.edu.br
} 
MLD and evaluation of systolic BP, diastolic BP and HR after 10 minutes of initial rest, at the end of the implementation of the protocol in SP, PP and after 15 minutes of final rest. Results: No changes were found in systolic BP or diastolic BP before, during and immediately after the MLD session ( $p=0.57, p=0.20$, respectively). There was increased heart rate after the final 15 minute rest when compared to the HR after MLD in SP (72 \pm 1.9 vs. $76 \pm 1.9, \mathrm{p}=0.002)$, however, without clinical relevance. Conclusion: During a session of MLD with healthy young women, no significant hemodynamic changes occurred, demonstrating that this technique is safe from the cardiovascular point of view.

Keywords: Drainage. Blood pressure. Heart rate.

\section{Resumo}

Introdução: A Drenagem Linfática Manual (DLM) tem por objetivo criar diferenciais de pressão para promover o deslocamento da linfa e do fluido intersticial, objetivando a sua recolocação na corrente sanguínea, podendo, dessa forma, atuar nas variáveis responsáveis pela determinação da pressão arterial (PA). Objetivo: Investigar o comportamento das variáveis hemodinâmicas, como PA e Frequência Cardíaca (FC), durante e imediatamente após uma sessão de DLM. Materiais e métodos: 23 voluntárias jovens e saudáveis com idade média de $22 \pm 2,97$ anos (18-29), foram submetidas a uma sessão de DLM e avaliação da PA Sistólica, da PA Diastólica e da FC após 10 minutos de repouso inicial, no fim da realização do protocolo em DD, em DV e após 15 minutos de repouso final. Resultados: Não foram encontradas alterações na PA Sistólica e na PA Diastólica antes, durante e imediatamente após a sessão de DLM ( $p=0,57 ; p=0,20$, respectivamente); por outro lado, verificou-se aumento da FC após o repouso final de 15 minutos, quando comparado com a FC após a DLM em $D D(72 \pm 1,9$ vs. $76 \pm 1,9 ; p=0,002)$, porém sem relevância clínica. Conclusão: Durante uma sessão de DLM em mulheres jovens saudáveis, não ocorrem alterações hemodinâmicas importantes, demonstrando que essa técnica é segura do ponto de vista cardiovascular.

Palavras-chave: Drenagem. Pressão arterial. Frequência cardíaca.

\section{Introduction}

Manual Lymphatic Drainage (MLD) was created by the Danish biologist Emil Vodder and his wife Estrid Vodder in 1936, with this technique being characterized by some movements and orientation of the direction of lymph drainage. Later, in the same year as its creation, the systematization of the technique was published in Paris and with this several groups adopted these concepts, which are used to this day by professionals from different spheres of practice, such as beauticians, biologists, occupational therapists, nurses, and physiotherapists (1). The MLD technique is one of the cornerstones in the treatment of lymphedema, which is characterized by excessive and persistent accumulation of extravascular and extracellular fluid and proteins in the tissue spaces, the consequence of an inefficient lymphatic system and a chronic condition in which there is excessive accumulation of fluid in the interstice (2). This technique maintains the water balance of the interstitial spaces and also enables the elimination of degradation residues resulting from cellular metabolism (3).

The purpose of lymphatic drainage is to create pressure differentials to promote the displacement of lymph and interstitial fluid, aiming for their relocation into the blood stream (1), in order to empty the metabolic waste by maneuvering the lymphatic system and lymph nodes (4). It aims to improve lymphatic function and blood circulation (5), and to decongest the lymphatic vessels resulting in improved absorption and transport of liquids (6).

The maneuvers performed in MLD follow basic principles, with the evacuation (removal) and uptake (absorption) of the lymph (4). The external pressure, exerted by manual massage, should overcome the physiological internal pressure, which can reach 25 $40 \mathrm{mmHg}$ in the major lymphatic vessels (7). This technique should be carried out as follows: superficially at a slow, uniform and appropriate pace, as 
this negates the mechanical feeling and provides the maneuver with a pleasant feeling, at a determined frequency and correct time, where the pressure should always be directed in the physiological direction of lymphatic drainage (8). In the application of this technique it is essential for the patient to be in a comfortable position, preferably lying down, with the region to be treated uncovered (9).

Manual lymphatic drainage has been used in healthy people, post-mastectomy patients, in postoperative plastic surgery, for elephantiasis, nasal obstructions and colds, headaches, migraine, scarring, nerve pain (post-surgery), head and neck edema, rheumatic swellings, gynoid lipodystrophy, paralysis edema and other edema types. In spite of this, there are some absolute contraindications to performing this technique, such as acute thrombosis in the edematous region and acute bacterial or viral inflammation of the swollen region, among others, with some relative contraindications, such as hypotonia, pregnancy, bronchial asthma, cardiovascular diseases and arterial hypertension (9).

Hemodynamic changes originating from the use of MLD are not well described in the literature. Leduc et al. (5), with a group of patients with heart failure and lower limb edema, found significant changes in the heart rate when performing MLD only in the edema region, conversely, another study that performed MLD with elderly patients found no statistically significant differences (10). Based on this it is appropriate to investigate whether MLD promotes any acute change in the cardiovascular system, given that this technique promotes the displacement of extravascular fluid into the cardiovascular system which can change the current volume and perchance the blood pressure (BP) and the variables involved with this physiological phenomenon. Therefore, the aim of this study was to investigate the behavior of hemodynamic variables, such as BP and HR (Heart Rate), during and immediately after a Manual Lymphatic Drainage session.

\section{Materials and methods}

Sample

This is clinical trial type, quasi-experimental study, with a sample of 23 healthy young female volunteers aged $22 \pm 2.97$ (mean \pm standard deviation) between
18 and 29 years (minimum and maximum) selected by convenience. Women with any contraindication related to undergoing the MLD protocol and those who were using medications that might affect the autonomic nervous system were excluded from the sample. The study volunteers were instructed not to perform intense physical activity in the 24 hours preceding the study protocol, and not to consume alcohol or coffee in the 12 preceding hours. All participants read and signed the informed consent form prior the procedures being performed, in accordance with Resolution 196/96 of the National Health Council. This study was approved by the ethics committee of the institute under procedure No. 0279/11.

\section{Experimental protocol}

The volunteers were instructed to eliminate urine prior to the MLD (5) procedure, then the anthropometric evaluation was performed, with the volunteers then remaining at rest for 10 minutes in the supine position (SP). After 10 minutes of rest the systolic blood pressure (SBP), diastolic blood pressure (DBP) and the HR at rest was measured using a digital sphygmomanometer OMRON - HEM 710 INT (11).

With the volunteers in the SP the MLD protocol was initiated. At the end of the realization of the Protocol in the SP the SBP, DBP and HR were again assessed, also with the patient in the SP. The volunteer was then asked to change position to the prone position (PP) for the continuation of the MLD protocol and when the MLD protocol in the PP was finished the volunteer was asked to return to the SP for the new measurement of SBP, DBP and HR. When finishing the MLD protocol the volunteer was asked to remain at rest for 15 minutes in a sitting position and the SBP, DBP and HR were again reevaluated.

\section{Lymphatic drainage}

Manual lymphatic drainage was carried out using the Leduc technique characterized by inciting or call-up maneuvers (radial to ulnar) and reabsorption or uptake maneuvers (ulnar to radial) (12) of the lymph nodes in the following sequence: supine position (breast, abdomen, upper and lower limbs); prone position (leg region, buttocks, back and chest). 
The following protocol guided the procedure: 1) with the patient in the supine position the therapist started with call-up of the axillary and brachial nodes of the breast, supra-mammary reabsorption, call-up of axillary and brachial nodes of the breast, infra-mammary reabsorption, call-up of axillary and brachial nodes of the breast, reabsorption diagonally above the breast, call-up of axillary and brachial nodes of the breast, reabsorption diagonally below the breast, call-up of axillary and brachial nodes of the breast, reabsorption of upper abdomen from medial to brachial ascending diagonally, call-up of axillary and brachial nodes of the breast. Subsequently, inguinal call-up, lower abdomen reabsorption from brachial to medial descending diagonally from the flanks to the pubis and inguinal call-up were performed.

In the upper limbs (ULs), call-up was performed for the axillary, deltoid, arm, elbow, forearm, palm, and finger nodes, with reabsorption of the fingers, forearm, palm and back of the hand, call-up of the elbow, reabsorption of the arm, and call-up of the axillary and deltoid nodes. In the lower limbs (LLs) call-up was performed for the inguinal, thigh, popliteal fossa, leg, malleoli, sole of the foot and toe nodes, with reabsorption of the toes, sole and instep of the foot, call-up of the malleoli, reabsorption of the inner anterior region of the leg, call-up of the popliteal fossa, reabsorption of the inner region of the thigh, and call-up the inguinal nodes. 2) With the patient in the prone position the therapist started with callup of the malleolar, inguinal, popliteal fossa, and calf nodes, reabsorption in the calf, call-up of popliteal fossa, inguinal, and posterior thigh, reabsorption of the posterior thigh, call-up of inguinal, iliac crest nodes, call-up of the gluteal nodes, reabsorption in the gluteal nodes, call-up in the inguinal, iliac crest nodes, call-up of brachial breast, axillary, and scapular nodes, reabsorption in the dorsal region, call-up of brachial breast, axillary and shoulder nodes. Each session lasted for one hour and fifteen minutes, with the technique application time being fifty minutes.

\section{Evaluation of heart rate and blood pressure}

Blood pressure was measured using a validated and calibrated digital sphygmomanometer OMRON HEM 710 INT (11). This was carried out using the left arm of the volunteer after the 10 minutes initial rest period, at the moment before the change of position, and the end of the MLD session. The BP and HR were also measured after 15 minutes of the MLD session.

\section{Statistical analysis}

Initially the normality (Kolmogorov-Smirnov) and the homocedasticity of the data distribution were tested, validating the use of parametric statistics. For the description of the sample, the central tendency and variability of the data were expressed as mean \pm standard deviation, minimum and maximum, while for the data used in the statistical inference, the results were presented as mean \pm standard error of the mean. A repeated measures analysis of variance (ANOVA) was used to compare the mean values of SBP, DBP and HR in the rest, PP, SP and final moments. Statistical calculations were performed using the Prism version 5.01 program (GraphPad, USA), considering a significance level of $5 \%$.

\section{Results}

The demographic characteristics of the sample are presented in Table 1.

No changes were observed in the SBP or DBP, before, during and immediately after the completion of the Manual Lymphatic Drainage, $p=0.57$ and $\mathrm{p}=0.20$ respectively (Figure 1 ).

Conversely, after the final rest of 15 minutes in a sitting position, the HR was higher than after the completion of the MLD in the SP $(72 \pm 1.9 \mathrm{bpm} v s$. $76 \pm 1.9$ bpm; $p=0.002$ ) - Figure 2 .

Table 1 - Demographic characteristics of the sample

\begin{tabular}{lcc}
\hline \multicolumn{1}{c}{ Variables } & Mean \pm SD & $\begin{array}{c}\text { Minimum - } \\
\text { Maximum }\end{array}$ \\
\hline Age & $22 \pm 2.97$ & $(18-29)$ \\
Body weight & $60 \pm 9.05$ & $(46-80)$ \\
Height & $1.62 \pm 0.07$ & $(1.43-1.73)$ \\
BMl & $22.9 \pm 2.54$ & $(17.4-27.4)$ \\
SBP rest & $121.1 \pm 9.64$ & $(101-138)$ \\
DBP rest & $74.65 \pm 9.2$ & $(60-99)$ \\
HR rest & $78.2 \pm 9.81$ & $(63-104)$ \\
\hline
\end{tabular}

Note: $\mathrm{SD}=$ Standard deviation; $\mathrm{BMI}=$ body mass index; $\mathrm{SBP}=$ systolic blood pressure; DBP = diastolic blood pressure; HR = heart rate. 


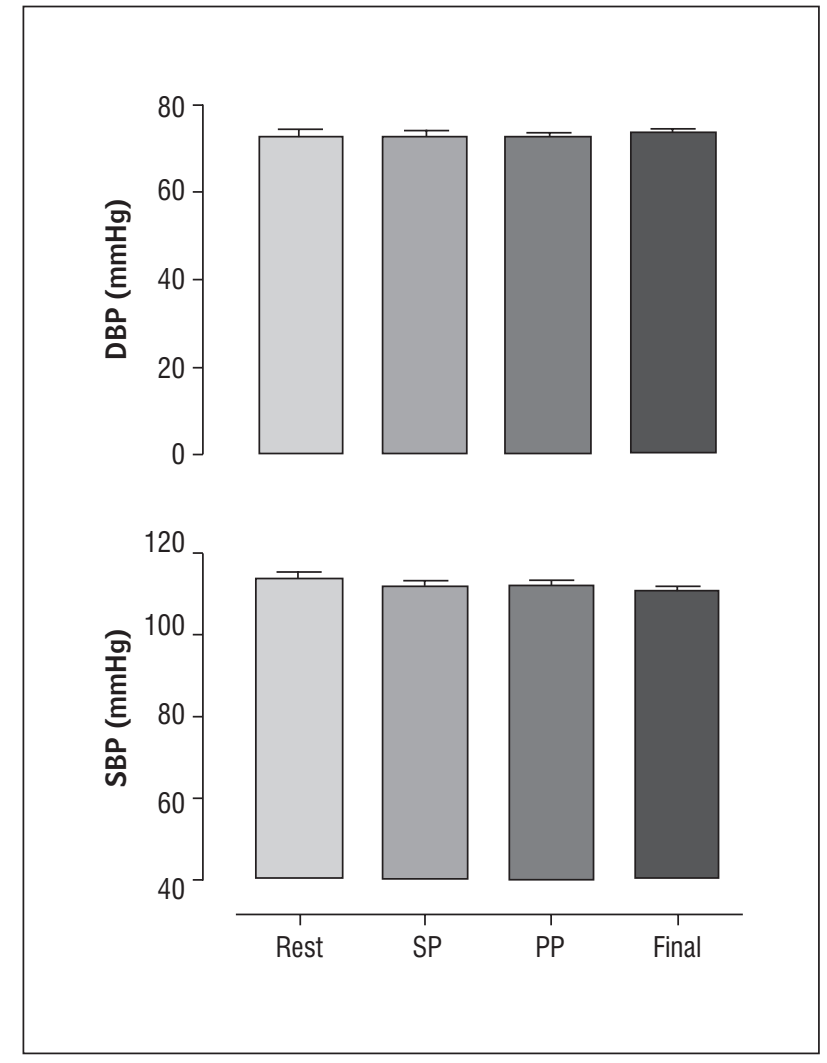

Figure 1 - Behavior of the systolic and diastolic blood pressure before, during and immediately after MLD

Note: Systolic blood pressure (SBP); diastolic blood pressure (DBP); supine position (SP); prone position (PP).

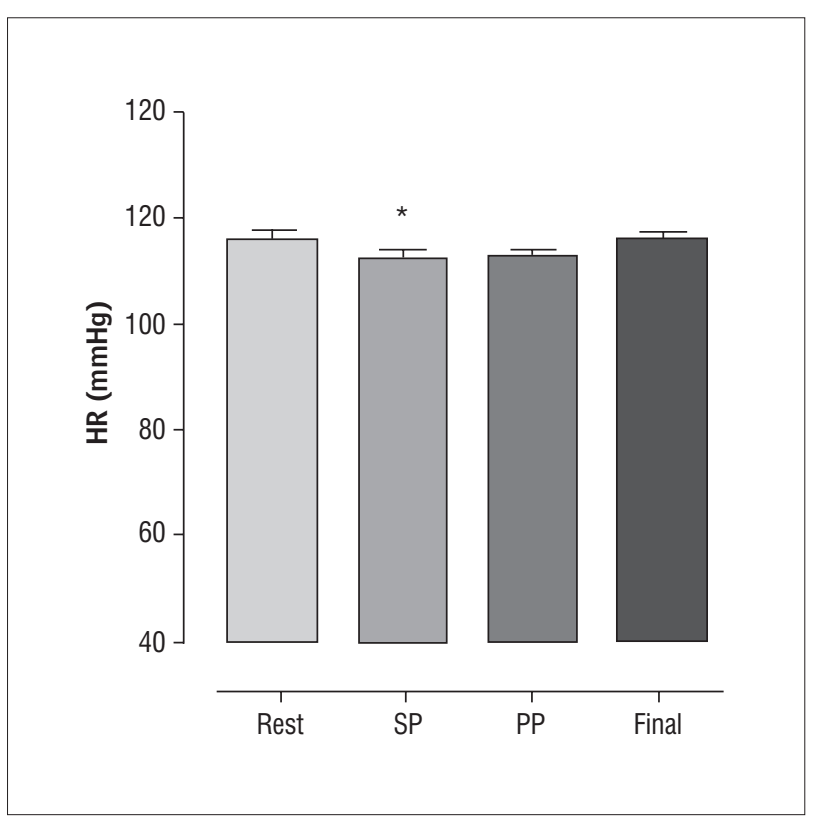

Figure 2 - Behavior of heart rate before, during and immediately after MLD

Note: Supine position (SP); prone position (PP); heart rate (HR).

\section{Discussion}

This study contributes to the body of knowledge by addressing the behavior of cardiovascular variables in young, healthy women that underwent a MLD session employing the Leduc technique. The behavior of the BP during MLD is a factor discussed in the clinical practice and some professionals consider it to be a contraindication to performing the technique in patients with systemic hypertension, as it is believed that MLD can further enhance the BP values after its performance, however, little evidence directly addressed the issue. In the present study, the behavior of BP and HR was verified during and immediately after a MLD session.

Changes in BP during and after a MLD session can be justified by the physiology involved in the technique and in the responses to the application of this procedure. Primarily, the physiological function of the lymphatic system needs to be addressed, as this is responsible for collecting the interstitial fluid and relocating it into the blood-vascular system (4). The MLD technique uses graded and constantly changing pressures, thereby mimicking the contractions of the smooth muscle of the lymphatic vessels and accompanying their rhythm (13).

Manual lymphatic drainage increases lymphatic transport, helping in the removal of interstitial fluid; the method consists of a pressure phase followed by a relaxation phase (14). The lymphatic system has several important functions, such as the control of macromolecular homeostasis, absorption of lipids, immune function and the control of interstitial fluids (15). Its main role is to remove fluid and proteins from the interstitial spaces, and the elimination of these elements is only possible through the lymphatic capillary membrane, as this is more permeable than the blood capillary membrane (16). As it is a secondary blood circulation route, it permits the draining of a filtrate from the blood, called lymph, from interstitial space into the blood vascular system and is responsible for transporting the lymph from the periphery to the center in one direction $(16,17)$.

A second point to be addressed is the function of the MLD technique, which consists of directing the fluid from the interstitial space to the drainage center, through specialized kinesic maneuvers called "Manual Lymphatic Drainage". This external compression is responsible for promoting a pressure differential between the extremities, thereby moving the fluid 
contained in a lymph vessel, allowing a reduction of pressure within the lymphatic vessel and aiding the entry of the excess liquid contained in the interstitium into the interior through the pressure difference (4).

The maneuvers are performed rhythmically, slowly and gently in the direction of the lymphatic circulation and about the lymph nodes (18). The interstitial fluid removed and relocated into the lymphatic vessels, is directed to the vascular system, in turn increasing the volume in the intravascular bed, which can interfere with the BP and HR values so that the $\mathrm{BP}$ is expressed by the cardiac output and peripheral vascular resistance (19). Any change in these components can interfere with the pressoric levels and during MLD changes in cardiac output are possible.

In the present study no changes in BP values were observed when the values obtained while resting, during the MLD, and after the procedure were compared, as presented in (Figure 1). Most probably no differences were found because all the study volunteers were healthy and the cardiac and vascular components that generate and BP and are controlled by complex mechanisms were healthy, thereby allowing the regulation and maintenance of the variation of the $\mathrm{BP}$ from moment to moment, thus controlling the size of the vessels, the vascular reactivity, the fluid distribution into and out of the vessels and the cardiac output (20). In addition, the BP is not governed by a single system, but by an interrelationship of mechanisms that perform specific functions, divided into fast and slow control mechanisms (21-23).

Fast control is performed by the baroreflex that is activated by arterial baroreceptors, which are mechanoreceptors (24). The arterial baroreceptors constitute one of the most important BP control mechanisms, these being free, branched nerve endings, which are primarily in the carotid sinus and the aortic arch walls (25). For baroreceptor activation to take place, a distension of the vascular walls has to occur, with them then acting as mechanoreceptors that regulate the BP through the reflex regulation of HR, cardiac output, myocardial contractility, and peripheral vascular resistance (26).

In the present study there may have been an increase in intravascular volume and therefore cardiac output, thus promoting the stimulation of the baroreceptors, with these acting to maintain the SBP and DBP values of the volunteers, also considering that the subjects were healthy and most probably had healthy systems. In the study by Nakamura et al.
(10) where, in a group of eight elderly women with the BP measured using an aneroid sphygmomanometer, there were no changes in BP values after the MLD sessions.

Another important factor that should be taken into consideration is the urge to urinate after the MLD technique, which, according to Krupek et al. (12), is commonly reported by individuals who perform the procedure. In this study the amount of urine pre and post MLD was compared and, after analysis of the results, an increase in urine after the MLD session compared to the urine sample before MLD was observed, however, without statistical significance. In the present study, some participants presented this need for urination, which can be related to the inhibition of ADH (antidiuretic hormone). The main role of this hormone is to conserve body water and regulate the tonicity of the bodily fluids, with its action occurring in the renal collecting tubules and ducts. Minimum amounts are required for the antidiuretic action, however, when $\mathrm{ADH}$ is present in higher amounts, it causes a powerful constriction of the arterioles of the entire body and consequently the increase in BP (27).

The urge to urinate present in some volunteers may be related to the inhibition of this hormone, considering that in circumstances where there is a low plasma concentration caused by the increase in circulating fluid possibly generated by MLD, there is less absorption of water into the renal distal collector tubules, promoting the excretion of urine for the maintenance of the plasma concentration, which can thus influence the reduction of intravascular volume and maintenance of the pressoric values $(28,29)$.

The other variable analyzed in this study was the HR, which underwent minor changes during the MLD, showing statistical differences between the HR in the final rest period when compared to the $\mathrm{HR}$ at the end of the MLD in the SP. After 15 minutes of final resting the HR was higher than the HR after the completion of MLD in the SP, as shown (Figure 2), however it should be noted that the difference found has no clinical relevance and probably the difference between these values originated from the manipulation of the volunteer for placement of the device and evaluation of the variables investigated in this study, as the device had to be removed between each measurement to make it possible to perform the MLD technique correctly. Furthermore, this may have been because the measurement of BP at rest after the MLD was performed 
with the patient sitting, with this change of the position of the volunteer being required so that after a MLD session the patient did not remain lying down, thereby increasing the external validity of the study.

The study of Leduc et al. (5), however, presented a significant reduction in HR after MLD when compared to the HR prior to the MLD, which may have been justified by the application of the technique only in the lower limbs in nine patients with congestive heart failure and edema of the lower limbs. This result was also reported by Nakamura et al. (10), who performed the technique with 8 elderly people, where the HR after the MLD decreased when compared to the HR prior to MLD, however, without statistical significance. Furthermore the regions in which the technique was applied were not described in the study, which may have influenced the results when compared with the present study, in which the technique was applied to the entire body except the face.

\section{Conclusion}

In the present study it was found that during a MLD session with healthy young women, significant hemodynamic changes do not occur, showing that this technique is safe from the cardiovascular point of view. The changes found in the heart rate of the volunteers after MLD, despite presenting statistical differences, are not relevant from a clinical point of view. Further studies with MLD over the entire body, in specific groups of patients with cardiovascular diseases or risk factors for their development, for example, systemic hypertension and congestive heart failure, are needed to affirm the safety of the MLD technique.

\section{References}

1. Godoy JMP, Godoy MFG. Drenagem linfática manual: novo conceito. J Vasc Br. 2004;3(1):77-80.

2. Veiros I, Nunes R, Martins F. Complicações da mastectomia: linfedema do membro superior. Acta Med Port. 2007;20:335-40.

3. Meirelles MCCC, Mamede MV, Souza L, Panobianco MS. Avaliação de técnicas fisioterapêuticas no tratamento do linfedema pós-cirurgia de mama em mulheres. Rev Bras Fisioter. 2006;10(4):393-9.
4. Piccinin AM, Mello PB, Bem DM, Silva A, Rosa PV. Redução do edema em membros inferiores através da drenagem linfática manual: um estudo de caso. Rev Inspirar Mov Saude. 2009;1(2):10-4.

5. Leduc O, Crasset V, Leleu C, Beptiste N, Koziel A, Delahie $\mathrm{C}$, et al. Impact of Manual Lymphatic Drainage on hemodynamic parameters in patients with heart failure and lower limb edema. Lymphology. 2011; 44(1):13-20.

6. Leal NFBS, Carrara HHA, Vieira KF, Ferreira CHJ. Tratamentos fisioterapêuticos para o linfedema pós-câncer de mama: uma revisão de literatura. Rev Latino-am Enfermagem. 2009;17(5):730-6. doi: 10.1590/S010411692009000500021.

7. Guirro E, Guirro R. Fisioterapia dermato-funcional. 3. ed. São Paulo: Manole; 2004.

8. Soares MM, Sancho AG, Lucena RS, Silva DD. Abordagem fisioterapêutica no linfedema secundário pósvulvectomia com linfadenectomia inguinal. Revista Cient HCE. 2007;3(2):60-9.

9. Herpertz U. Edema e drenagem linfática. 2. ed. São Paulo: Roca; 2006.

10. Nakamura CM, Vanini TM, Chingui LJ, Silva CA. Avaliação de repercussões cardiovasculares da drenagem linfática manual em mulheres idosas. Anuário da Produção de Iniciação Científica Discente. 2010; 13(17):43-51.

11. Coleman A, Freeman P, Steel S, Shennan A. Validation of the Omron MX3 Plus oscillometric blood pressure monitoring device according to the European Society of Hypertension international protocol. Blood Press Monit. 2005;10(3):165-8.

12. Krupek T, Oliveira LP, Moraes LRS, Vizoni SL. Análise Laboratorial de urina pós drenagem linfática Saud Pesq. 2012;5(1):75-85.

13. Ornelas FA, Rodriguez JRP, Uemura G. Análise sensitiva convencional no pós-cirúrgico de câncer de mama. Rev Bras Mastol. 2009;19(2):53-9.

14. Tambour M, Tange B, Christensen R, Gram B. Effect of physical therapy on breast cancer related lymphedema: protocol for a multicenter, randomized, singleblind, equivalence Trial. BMC Cancer. 2014;14:239. doi:10.1186/1471-2407-14-239. 
15. Rezende LF, Pedras FV, Ramos CD, Gurgel MSC. Avaliação das compensações linfáticas no pós-operatório de câncer de mama com dissecção axilar através da linfocintilografia. J Vasc Bras. 2008;7(4):370-5. doi: 10.1590/S1677-54492008005000002.

16. Rezende LF, Pedras FV, Ramos CD, Gurgel MSC. Função Linfática do membro superior no pré-operatório de câncer de mama. Rev Assoc Med Bras. 2011;57(5):5404. doi: 10.1590/S0104-42302011000500012.

17. Ridner SH, Poage-Hooper E, Kanar C, Doersam JK, Bond SM, Dietrich MS. A pilot randomized trial evaluating low-level laser therapy as an alternative treatment to Manual Lymphatic Drainage for breast cancer-related lymphedema. Oncol Nurs Forum. 2013; 40(4):383-93. doi: 10.1188/13.0NF.383-393.

18. Antonio FE, Santos PS, Tamara MV, Chingui LJ, Silva CA. Avaliação de parâmetros bioquímicos na drenagem linfática manual em mulheres idosas. Anuário da Produção de Iniciação Científica Discente 2010; 13(17):53-61.

19. Brandão DSN, Almeida AF, Silva JC, Oliveira RGCQ, Araújo RC, Pitangui ACR. Avaliação da técnica de drenagem linfática manual no tratamento do fibro edema gelóide em mulheres. ComScientiae Saúde. 2010;9(4):618-24.

20. Luna RL. Conceituação da hipertensão arterial e sua importância epidemiológica. Rev SOCERJ. 2002; 15(4):203-9.

21. Wehwein EA, Joyner MJ. Regulation of blood pressure by the arterial baroreflex and autonomic nervous system. Handb Clin Neurol. 2013;117:89-102. doi: 10.1016/B978-0-444-53491-0.00008-0.

22. Okutucu S, Karakulak UN, Kabakçi G. Circadian blood pressure pattern and cardiac autonomic functions: different aspects of same pahophysiology. Anadolu Kardivol Derg. 2011;11(2):168-73.

23. Estañol B, Porras-Betancourt M, Sanchez-Torres Z, Martinez-Memije R, Infante 0, Senties-Madrid H. Neural control of the peripheral circulation and blood pressure. Arch Cardiol Mex. 2009;2(Suppl 2):109-16.

24. Fazan VPS. Nervo depressor aórtico: importância dos estudos morfológicos na compreensão dos mecanismos fisiológicos do controle da pressão arterial? Rev Bras Hipertens. 2002;9(4):413-5.
25. Haibara AS, Santos RAS. Descobrimento e importância dos barorrecptores. Rev Bras Hipertens. 2000; 7(2):113-5.

26. Wehrwein EA, Joyner MJ, Hart ECJ, Wallin BG, Karlsson T, Charkoudian N. Blood pressure regulation in humans: calculation of an "error signal" in control of sympathetic nerve activity. Hypertension. 2010;55(2):26469. doi: 10.1161/HYPERTENSIONAHA.109.141739.

27. Canali ES, Kruel LFM. Respostas hormonais ao exercício. Rev Paul Educ Fís. 2001;15(2):141-53.

28. Naves LA, Vilar L, Costa ACF, Domingues L, Casulari LA. Distúrbios na secreção e ação do hormônio antidiurético. Arq Bras Endocrinol Metab. 2003;47(4):46781. doi: 10.1590/S0004-27302003000400019.

29. Irigoyen MC, Lacchini S, De Angelis K, Michelini LC. Fisiopatologia da hipertensão: o que avançamos? Rev Soc Cardiol Estado de São Paulo. 2003;13(1):20-45.

Received: $11 / 10 / 2013$

Recebido: 10/11/2013

Approved: 06/21/2014

Aprovado: 21/06/2014 